\title{
New record and expansion of the geographic distribution of Parodia mueller-melchersii (Frič ex Backeb.) N. P. Taylor (Cactaceae) in the southern region of Rio Grande do Sul, Brazil
}

\author{
Renan Silveira Pittella ${ }^{* *}$ (D), Thamiris Barbosa dos Santos ${ }^{2}$ (i) , Hélio Ramirez Farias ${ }^{3}$ (i) \\ ' Universidade Federal do Rio Grande do Sul, Departamento de Ecologia, Avenida Bento Gonçalves, 9500, \\ CEP 91501-970, Porto Alegre, Rio Grande do Sul, Brasil \\ *Autor para correspondência: renanpittella@gmail.com \\ 2 Universidade Federal do Rio Grande do Sul, Departamento de Paleontologia e Estratigrafia, Avenida Bento Gonçalves, \\ 9500, CEP 91501-970, Porto Alegre, Rio Grande do Sul, Brasil \\ ${ }^{3}$ Instituto Meridionalis de Estudos da Flora, Caixa Postal 64, CEP 96300-000, Jaguarão, Rio Grande do Sul, Brasil
}

Recebido em 14.X.2019

Aceito em 25.V.2020

DOI 10.21826/2446-82312020v75e2020009

\begin{abstract}
Parodia mueller-melchersii is an endemic species from the Pampa Biome, presenting severely fragmented populations. In this study, we describe a new record of the species from the Municipality of Jaguarão, located in the extreme South of the State of Rio Grande do Sul (Brazil). This new record increases the distribution of $P$. mueller-melchersii by approximately $260 \mathrm{~km}$ to the southeast and represents its southernmost known point of occurrence from now. Additionally, we present illustrations and comments about the environment where the species was found and a short discussion about the conservation status of natural populations in the State.
\end{abstract}

Keywords: biogeography, cactus, grasslands, threatened species

RESUMO - Novo registro e ampliação da distribuição geográfica de Parodia mueller-melchersii (Frič ex Backeb.) N. P. Taylor (Cactaceae) na região sul do Rio Grande do Sul, Brasil. Parodia mueller-melchersii é uma espécie endêmica do Bioma Pampa, apresentando populações fortemente fragmentadas. Neste estudo, descrevemos um novo registro da espécie para o Município de Jaguarão, localizado no extremo sul do Estado do Rio Grande do Sul. Este novo registro aumenta a distribuição de P. mueller-melchersii em aproximadamente 260 km ao sudeste e representa o ponto de ocorrência mais ao sul até o momento. Também apresentamos ilustrações e comentários sobre o ambiente onde a espécie foi encontrada, bem como uma pequena discussão sobre o status de conservação das populações naturais no estado.

Palavras-chave: biogeografia, cacto, campos, espécie ameaçada

\section{INTRODUCTION}

Cactaceae Juss. is almost endemic to the American continent where it has approximately 120 genera with over 1300 species distributed from Canada to the Patagonia (Hunt et al. 2006). The Neotropical region is known to present the highest species richness of this family (Zappi \& Taylor 2008), with Mexico, the southwest of the United States, the central Andes and eastern Brazil as main centres of diversity (Zappi et al. 2018). Recognized as the third most important centre of Cactaceae diversity (Silva et al. 2011), Brazil holds 39 genera (14 endemics), about 261 species and 92 subspecies (BFG 2015). These are distributed across all phytogeographic domains of the country, yet predominantly at the Caatinga, the Cerrado, the Atlantic Forest (Taylor \& Zappi 2004) and the Pampa (Carneiro et al. 2016).

Parodia Speg. comprises a group of terrestrial plants with globose to short- cylindrical stem bearing prominent ribs. It is distributed in Argentina, Bolivia, Paraguay, Uruguay and Brazil. At the latter country, this genus is only present at the southern States (MS, PR, RS, SC), dwelling in open fields and vegetation associated with rocky outcrops (Flora do Brasil 2019). According to Hunt et al. (2006) the genus initially comprised 58 species; however, several were later published, resulting in the currently 94 accepted taxa, including the subspecies (The Plant List 2013). Many of these taxa present a limited geographic distribution (Machado et al. 2008). In the Brazilian state of Rio Grande do Sul, 32 species are found, some of them 13 being endemic (Carneiro et al. 2016).

Parodia mueller-melchersii (Frič ex Backeb) N.P. Taylor is considered endemic to the Pampa Biome, where its occurrence is predominantly associated with rocky outcrops and stony soils (Carneiro et al. 2016). It is found mainly in northern Uruguay and west of Rio Grande do Sul (Hunt et al. 2006). However, it is not abundant and some of its populations are severely affected by livestock 
activities and by Eucalyptus plantations, according to an evaluation made by Larocca et al. (2013) following the guidelines of the International Union for Conservation of Nature (IUCN). Consequently, it is considered Endangered [criterion A4ac + B1ab (iii, v)] in Rio Grande do Sul (FZB 2014), where its populations known so far are restricted to the western region (Anceschi \& Magli 2018) and have been continually declining (IUCN 2019).

In this study, we present an expansion of the geographic distribution of $P$. mueller-melchersii and include a new record for the occurrence of the species in the extreme south of Rio Grande do Sul State. In addition, we present photos and comments about the environment where the species occurs and a brief discussion about the conservation status of their populations.

\section{MATERIAL AND METHODS}

This record is the result of a cactus survey conducted on a native field fragment in the rural area of Jaguarão, Rio Grande do Sul (32³3'57'S 53²2'33'W). Following the recommendations of Meijaard and Nijman (2014) for endangered species and aiming at the preservation, the exact coordinates of the population are not given here, however they will be available for research purposes, on request. We found a population of $P$. mueller-melchersii on a rocky outcrop located in a rural property on a field trip made in August 2018. To create the geographic distribution map (Fig. 1) we used the observation data of P. mueller-melchersii population from our field trip and the information available in the databases SpeciesLink, Reflora, Ralph Martin's field number finder and Global Biodiversity Information Facility combined with the species distribution information reported in the literature. The relevant specimen data were recorded in the field and the plants photographed with a Canon EOS Rebel T5 digital camera.

The species has been identified based on specialized literature (Anceschi \& Magli 2018, Carneiro et al. 2016, Hunt et al. 2006). We also examined living specimens under cultivation in the cactus collection of Fundação Zoobotânica do Rio Grande do Sul and digital images available in the same databases used to create the distribution map. The nomenclature used to designate phytophysiognomies follows the proposal of Carneiro et al. (2016).

\section{RESULTS}

Parodia mueller-melchersii (Frič ex Backeb) N.P. Taylor, Bradleya; Yearbook of the British Cactus and Succulent society 5:93. 1987.

Synonyms: Notocactus eugeniae Vliet, Notocactus gutierrezii W.R. Abraham, Notocactus mueller-melchersii Fric ex Backeb, Notocactus rutilans Daniker \& Krainz, Notocactus veenianus Vliet, Parodia mammulosa subsp. eugeniae (Vliet) Hofacker, Parodia mueller-melchersii subsp. gutierrezii (W.R. Abraham) Hofacker, Parodia mueller-melchersii subsp. winkleri (Vliet) Hofacker, Parodia rutilans (Daniker \& Krainz) N.P. Taylor, Parodia rutilans subsp. veeniana (Vliet) Hofacker.

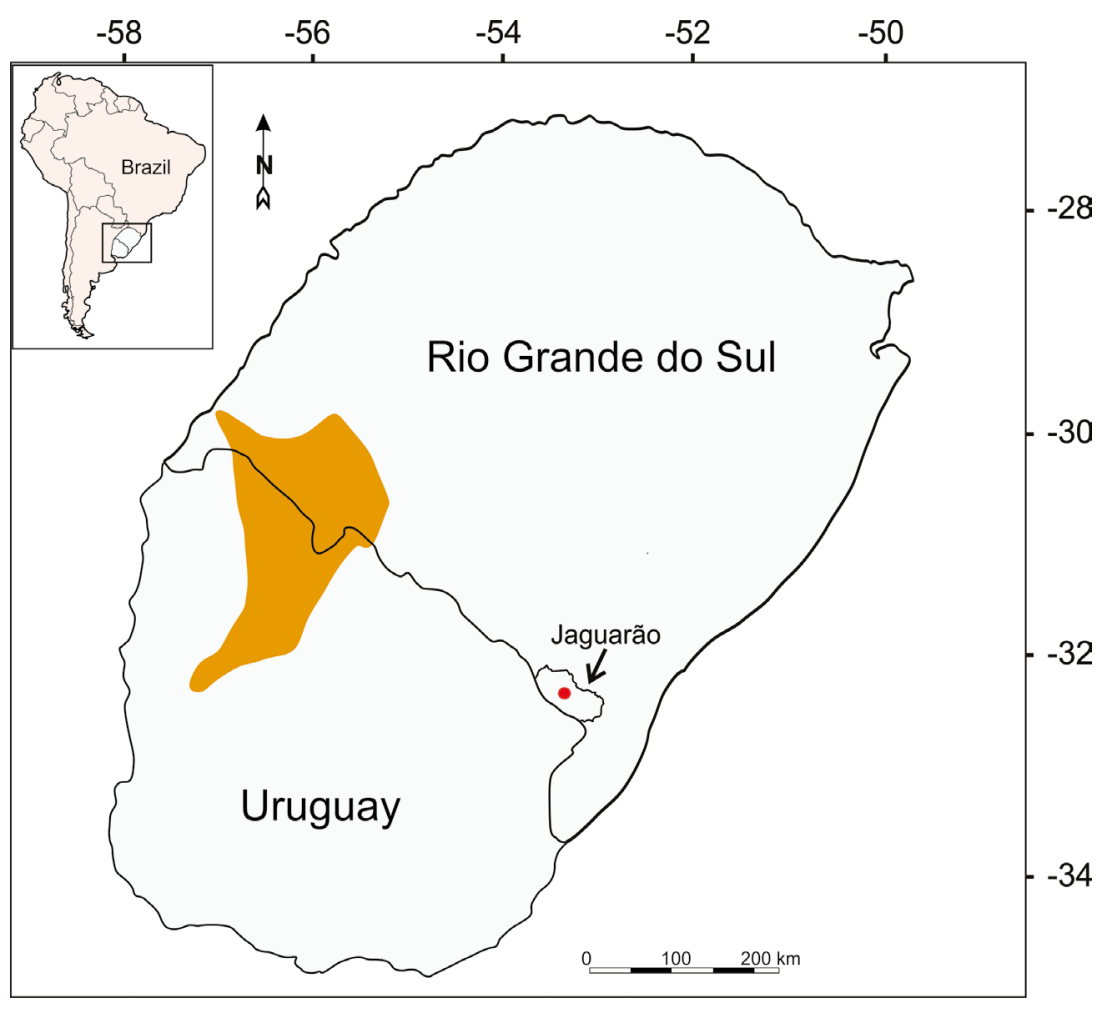

Fig. 1. Parodia mueller-melchersii distribution map. Previous records (orange); New record of occurrence from this study (red). 
New record: Brazil, Rio Grande do Sul, Jaguarão (32³3'57'S 5322'33”W), $3^{\circ}$ Subdistrito Quilombo, observed by Renan Pittella, Thamiris Barbosa e Hélio Ramirez, 18.VIII.2018 (population size ca. 180 individuals) (Fig. 1).

Voucher: Parodia mueller-melchersii, BRASIL, RIO GRANDE DO SUL, Jaguarão, $3^{\circ}$ Subdistrito, Fazenda Rincão da Coronilha, 22.X.2019, R. Farias-Singer, R. Pittella, H. Ramirez, P. Martins \& F. S. Petry 2.051 (HAS 96644).

Additional specimens examined: BRASIL, RIO GRANDE DO SUL, Santana do Livramento, road to Cerros Verdes, 5.XII.2005, Machado M. 692 (HUEFS 105018 [image]); road to Cerros Verdes, 15.XI.2006, Machado M. 893 (HUEFS 135168 [image]); Uruguaiana, Estancia Juquiri, 21.X. 2009, Ari Delmo Nilson e Ricardo Aranha Ramos s/nº (FZB/RS CAC329); No location data,
4.V.1964, No collector data (WAG 1878616 [image]); SOUTH AMERICA, 16.V.1969, Buining $\mathrm{s} / \mathrm{n}^{\circ}$ (WAG 1878617 [image]); No location data, 4.IV.1966, B. K. Boom 44650 (WAG 1918811 [image]).

Description: Solitary or clustered cactus, terrestrial, elongated globular shape, $10-15 \mathrm{~cm}$ in height $\mathrm{x} 10-15 \mathrm{~cm}$ in diameter, dark green, poorly pronounced ribs (21-14), with small circular tubercles, areoles with white wool in young plants; central spines 1-3, 4-20 mm long, straight, subulate to acicular, whitish or light yellow, dark at base and apex; radial spines $14-18$ or more, 2-8 mm long, slightly acicular, divergent, white; flower ca. $3 \times 4.5-5 \mathrm{~cm}$, yellow (pale golden-yellow; citrus yellow) or pink; elongated fruit with thin walls, ca. $2-3 \mathrm{~cm}$ high $\times 1.8 \mathrm{~cm}$ in diameter, dry, with the appearance of white felt, with reddish thorns, black seeds (Figs. 2A-D).
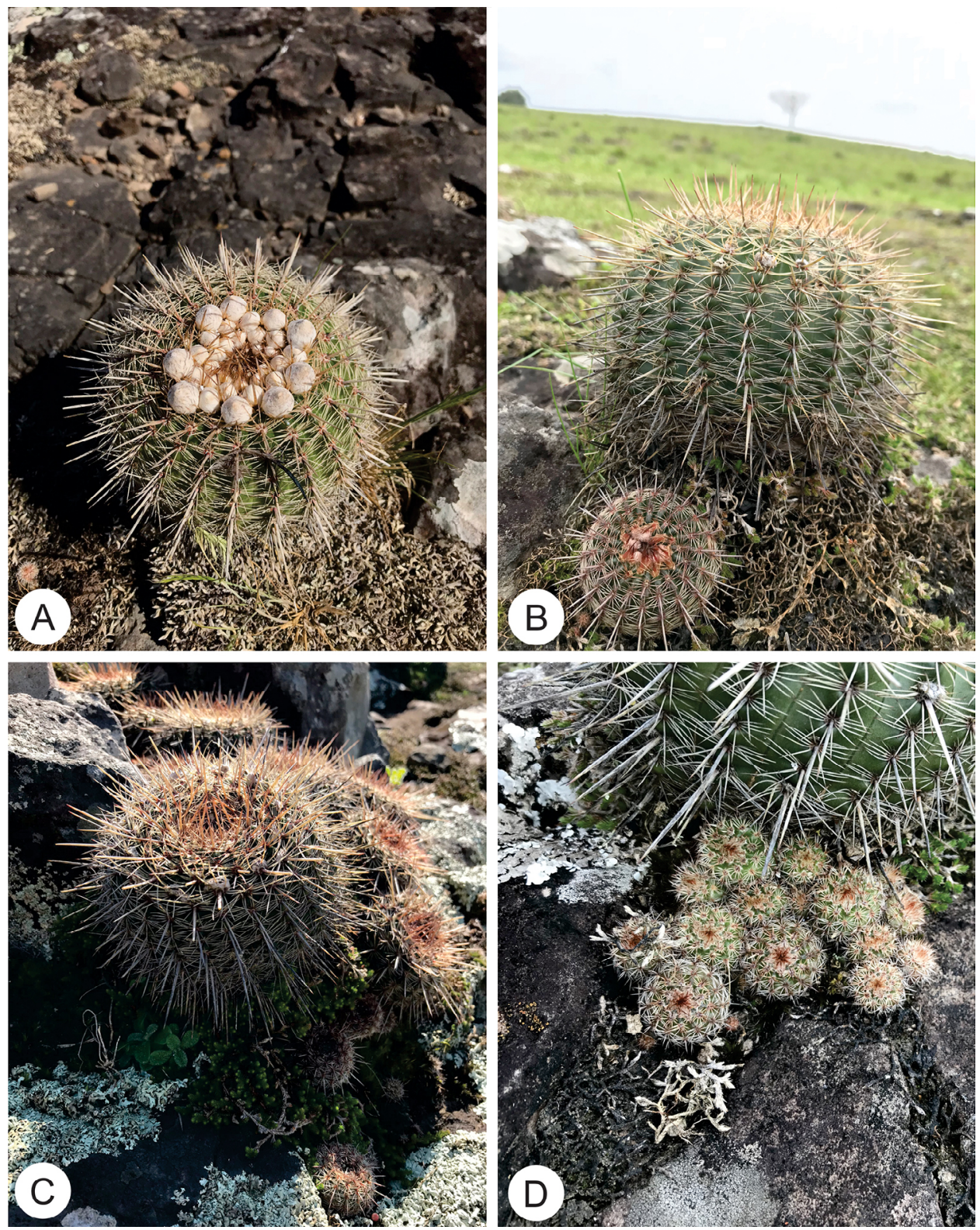

Figs. 2A-D. Parodia mueller-melchersii. A. General appearance (frontal view); B. General appearance (lateral view); C. Habitus; D. Juvenile specimens. 
The specimens found in this study are in accordance with the above description adapted from Anceschi \& Magli (2018) and Carneiro et al. (2016). Although the subspecies P. mueller-melchersii subsp. gutierrezii is no longer a valid name, this name applies for the populations with pink flowers. However, the individuals of the population reported in this study only have yellow flowers.

According to Anceschi \& Magli (2018), P. muellermelchersii differs from Parodia mammulosa (Lem.) N.P. Taylor, the most morphologically similar species, by its higher number of ribs (21-24 vs. 13-21) (Figs. 3A-B), by its not-flattened central spines and by its thinner radial spines (Figs. 3C-D). According to Carneiro et al. (2016) the flowers of $P$. mammulosa $(1-3.5 \times 2-3.5 \mathrm{~cm})$ have a funiliform, densely wooly hypanthium, with bristly thorns which is absent in the flowers of P. mueller-melchersii flowers. Additionally, we observed other differences regarding floral morphology in the populations of the two species found in this study, such as longer, lanceolate, pale golden-yellow tepals; the lobed, red-purple stigma with close lobes pointing upwards ("closed shape") in P. mueller-melchersii (Fig. 3E); while P. mammulosa presented flowers with shorter, tubular lanceolate tepals of bright golden-yellow coloration, lobed red-pink stigma with distant lobes pointing outside ("open shape") (Fig. 3F).

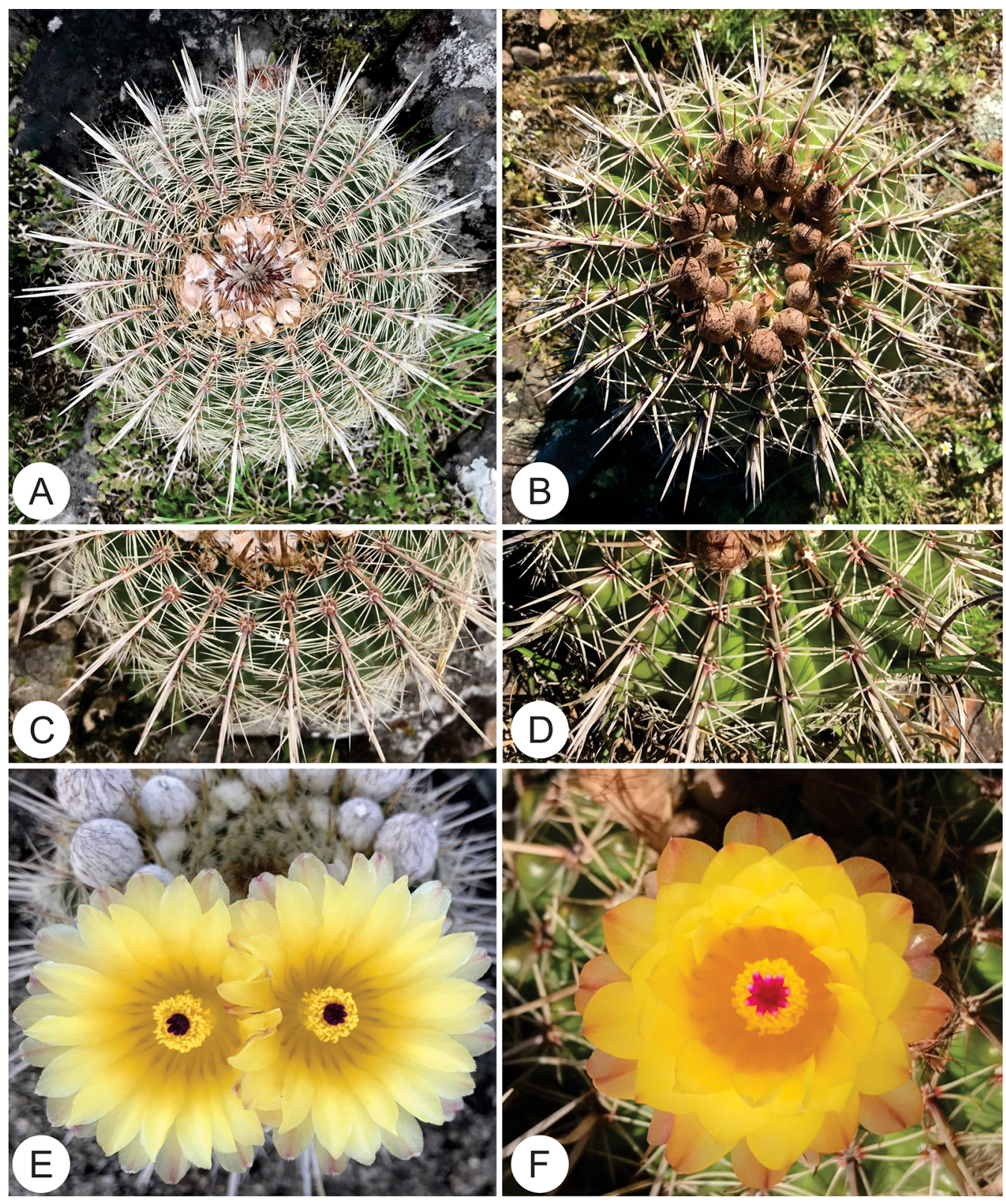

Figs. 3A-F. Morphological differences between P. mueller-melchersii and P. mammulosa. A. P. mueller-melchersii ribs; B. P. mammulosa ribs; C. P. mueller-melchersii spines; D. P. mammulosa spines; E. P. mueller-melchersii flower; F. P. mammulosa flower. 
Distribution and habitat: Currently, this species is known to occur in Rio Grande do Sul (BR) and Uruguay (Fig. 1); yet exclusively in the Pampa Biome, where inhabits rocky soils and outcrops at 150-300 m high (Anceschi \& Magli 2018). A natural population was found growing in a dry-field area (elevation 60-70 $\mathrm{m}$ above the sea level) in the shrub fields phytophysiognomy region in the $3^{\text {rd }}$ subdistrict of Jaguarão/RS. The place where the population occurs is characterized as a rocky place, composed by volcanic rocks from the Serra Geral Formation, slightly lighter in color compared to basalts strictu sensu, with crystallized quartz and volcanic glass in its composition (Glaucos Ribeiro personal communication); located on the hillside of a small hill (locally known as "coxilha"), surrounded by a vegetation dominated by grasses and bryophytes (Figs. 4A-B). Near the same region other species of cacti can be found associated with the same habitat, such as $P$. mammulosa, Parodia erinacea (Haw.) N. P. Taylor and Frailea gracillima (Lem.) Briton \& Rose.

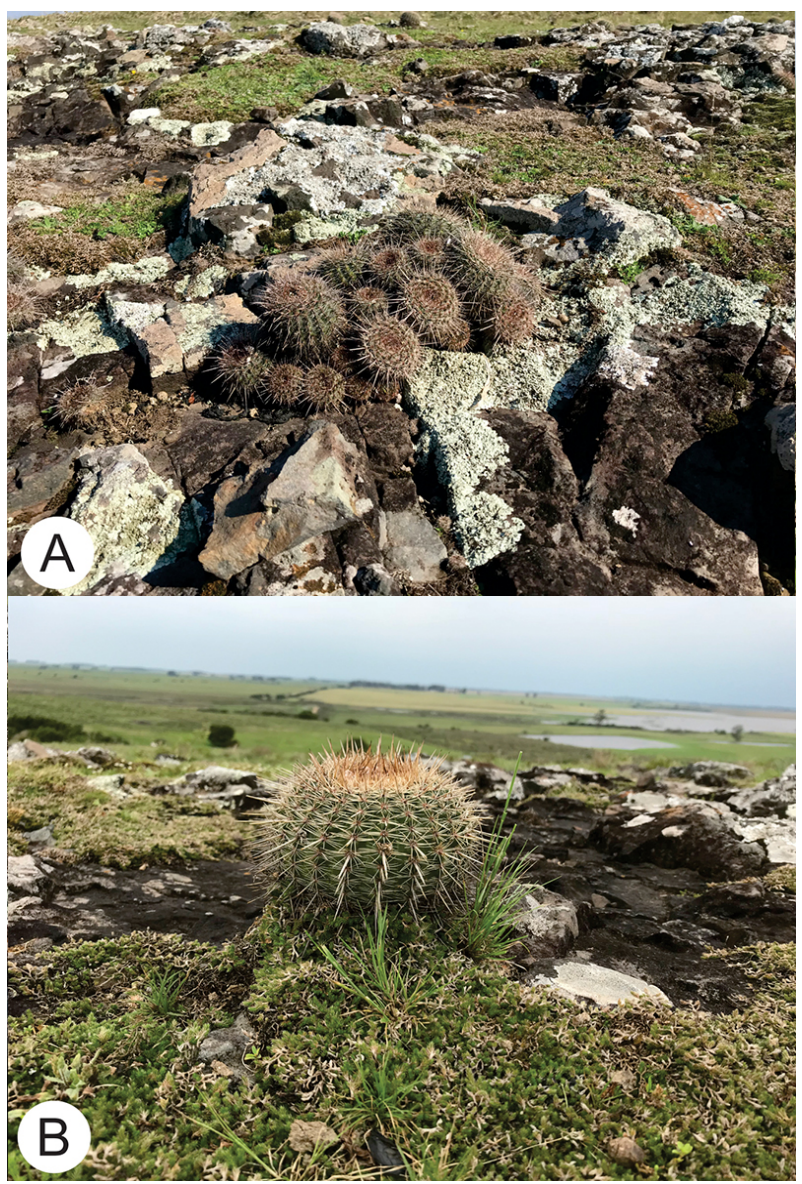

Figs. 4A-B. Parodia mueller-melchersii habitat in Jaguarão, RS. A. Rocky outcrop; B. Surrounding vegetation.

\section{DISCUSSION}

Parodia mueller-melchersii was originally known from northern Uruguay and western Rio Grande do Sul (Anceschi \& Magli 2018). The record for the region of the $3^{\text {rd }}$ subdistrict of the municipality of Jaguarão extends the geographical distribution by approximately $260 \mathrm{~km}$ southeast and represents the southernmost known locality of occurrence for the species. This record shows that $P$. mueller-melchersii is not restricted to the shallow soil fields at geomorphological unit Cuesta do Haedo, as was previously known (Carneiro et al. 2016). The population reported here occurs in a transitional region between the Planície Costeira (coastal fields) and Planalto Sul-riograndense (shrub fields) (Hasenack et al. 2010), in the extreme south of the state of Rio Grande do Sul.

According to Carneiro et al. (2016), this species hasn't been recorded in any protected area and faces a very high risk of extinction in the wild (IUCN category EN). However, it was already recorded near Cerros Verdes (see Additional specimens examined) which is an area located inside the APA do Ibirapuitã, a conservation area for sustainable use. Its extent of occurrence is small and populations are already declining due to several factors, among which the main threats are related to the intensive forestry and livestock activities developed at Rio Grande do Sul State. The record in Jaguarão was made in a privately rural area that develops activities of the same nature, corroborating the threat status and pressures that the species has been suffering in this region. The Municipality is located in a highly restricted area between southern Rio Grande do Sul and northern Artigas/UY $\left(\sim 500 \mathrm{~km}^{2}\right)$, an area with high richness of threatened cacti (Goettsch et al. 2015). In this sense, it is emphasized the need of measures such as these already suggested in literature (see Carneiro et al. 2016), like actions on environmental education (especially in rural areas) as well as to promote good practices in agricultural activities which could ultimately reflect on the conservation of the remaining natural cacti populations.

Our work increases the number of records in the Pampa Biome and expands the known area of occurrence for the species; which may be useful to understand its spatial distributional pattern and to assist in locating additional, as yet not perceived populations. In addition to contributing to future biogeographic studies, these data may also be useful for updating conservation status and for understanding other aspects of $P$. mueller-melchersii ecology. 


\section{ACKNOWLEDGMENTS}

We would like to thank Rosana Farias Singer for her help providing the voucher data; Glaucos Ribeiro for the help in identifying the geological Formation and rock classification; Leonel Fagundes and Claudio Farias for permission to conduct the study on their properties.

\section{REFERENCES}

Ancecschi, G., Magli, A. 2018. A synopsis of the genus Parodia Spegazzini s.1. (Cactaceae). Bradleya 36/2018:70-161.

BFG - The Brazil Flora Group. 2015. Growing knowledge: an overview of seed plant diversity in Brazil. Rodriguésia 66:1085-1113.

Cactus and Succulent Field Number Finder. Available at: http://www. fieldnos.bcss.org.uk/finder.html. Accessed on 08.08.2019.

Carneiro, A.M., Farias-Singer, R., Ramos, R.A., Nilson, A.D. 2016. Cactos do Rio Grande do Sul. Fundação Zoobotânica do Rio Grande do Sul, Projeto RS Biodiversidade, 224 p.

Flora do Brasil. 2019. Flora do Brasil 2020 [under construction]. Rio de Janeiro Botanical Garden. Available at: https://www.floradobrasil. jbrj.gov.br. Accessed on 25.08.2019.

FZB. 2014. Lista vermelha das espécies da flora ameaçadas de extinção do Rio Grande do Sul Available at: http://www.fzb.rs.gov.br/ conteudo/2403/?Informações_da_Biodiversidade. Accessed on 28.08.2019.

GBIF. 2019. Global Biodiversity Information Facility. Available at: http:// www.gbif.org/. Accessed on 08.08.2019.

Goettsch, B., Hilton-Taylor, C., Cruz-Piñón, G., Duffy, J.P., Frances, A., Hernandéz, H.M., Inger, R., Pollock, C., Schipper, J., Superina, M., Taylor, N.P., Tognelli, M., Abba, A.M., Arias, S., Arreloa-Nava, H., Baker, M.A., Bárcenas, R.T., Barrios, D., Braun, P., Butterwoth, C.A., Búrquez, A., Caceres, F., Chazaro-Basañez, M., Corral-Díaz, R., Perea, M.V., Demaio, P.H., Duarte de Barros, W.A., Durán, R., Yancas, L.F., Felger, R.S., Fitz-Maurice, B., Fitz-Maurice, W.A., Gann, G., Gómez-Hinostrosa, C., Gonzalez-Torres, L.R., Griffith, M.P., Guerrero, P.C., Hammel, B., Heil, K.D., Hernández-Oria, J.G., Hoffmann, M., Ishihara, M.I., Kiesling, R., Larocca, J., Luz, J.L.L., Loaiza, C.R., Lowry, M., Machado, M.C., Majure, L.C., Ávalos, J.G.M., Martorell, C., Maschinski, J., Méndez, E., Mittermeier, R.A., Nassar, J.M., Negrón-Ortiz, V., Oakley, L.J., Ortega-Baes, P., Ferreira, A.B.P., Pinkava, D.J., Porter, J.M., Puente-Martinez, R., Gamarra, J.R., Pérez, P.S., Martínez, E.S., Smith, M., Sotomayor,
J.M., Stuart, S.M., Muñoz, J.L.T., Terrazas, T., Terry, M., Trevisson, M., Valverde, T., Van Devender, T.R., Véliz-Pérez, M.E., Walter, H.E., Wyatt, S.A., Zappi, D., Zavala-Hurtado, A., Gaston, K.J. 2015. High proportion of cactus species threatened with extinction. Nature Plants:1-7.

Hasenack, H., Weber, E., Boldrini, I.I., Trevisan, R. 2010. Mapa de sistemas ecológicos da ecorregião das Savanas Uruguaias em escala 1:500.000 ou superior e relatório técnico descrevendo insumos utilizados e metodologia de elaboração do mapa de sistemas ecológicos. Porto Alegre: UFRGS.

Hunt, D.R., Taylor, N.P., Charles, G. 2006. The new cactus lexicon, text. Milborn Port, Text. Dh Publications, 373 p.

Hunt, D.R., Taylor, N.P., Charles, G. 2006. The new cactus lexicon, atlas of illustrations. Milborn Port, Text. Dh Publications, $527 \mathrm{p}$.

IUCN. 2019. The IUCN Red List of Threatened Species. Version 2019-2. Available at: https://www.iucnredlist.org/species/152677/664649\#p opulation. Accessed on 28.08.2019.

Larocca, J., Machado, M., Duarte, W. 2013. Parodia mueller-melchersii. The IUCN Red List of Threatened Species 2013: e.T152677A664649. Available at: http://dx.doi.org/10.2305/IUCN.UK.2013-1.RLTS. T152677A664649.en.

Machado, M.C., Nyffeler, R., Urs, E., Larocca e Silva, J.F. 2008. A New Species of Parodia (Cactaceae, Notocacteae) from Rio Grande do Sul, Brazil. Novon 18:214-219.

Meijaard, E., Nijman, V. 2014. Secrecy considerations for conserving Lazarus species. Biological Conservation 175: 21-24.

Reflora - Herbário Virtual. Available at: http://reflora.jbrj.gov.br/reflora/ herbarioVirtual/. Accessed on 08.08.2019.

Silva, S.R., Zappi, D.C., Taylor, N., Machado, M. 2011. Plano de ação nacional para a conservação das cactáceas. Série Espécies Ameaçadas $\mathrm{n}^{\mathrm{o}} 24$. Instituto Chico Mendes, $58 \mathrm{p}$.

SpeciesLink. 2019 [continuously updated]. Sistema de Informação Distribuído para Coleções Biológicas. Available at: http://www. splink.cria.org.br/. Accessed on 08.08.2019.

Taylor, N.P., Hunt, D. 1987. New and unfamiliar names of Cactaceae to be used in the European Garden Flora. Bradleya 5/1987: 91-94.

Taylor, N., Zappi, D. 2004. Cacti of eastern Brazil. Kew, Royal Botanic Gardens, $511 \mathrm{p}$.

The Plant List. Version 1.1. 2013. Available at: https://www.theplantlist. org. Accessed on 26.08.2019.

Zappi, D.C., Taylor, N. 2008. Diversidade e endemismo das Cactaceae na Cadeia do Espinhaço. Megadiversidade 4 (1-2):111-116.

Zappi, D.C., Taylor, N.P., Damasceno Jr., G.A., Pott, V.J., Machado, M.C. 2018. Check-list das Cactaceae do estado do Mato Grosso do Sul, Brasil. Iheringia Série Botânica 73 (supl.):169-173. 